\title{
Proximate composition of the leaves of Bambusa ventricosa, Oxytenanthera abyssinica and two varieties of Bambusa vulgaris
}

\author{
C. Antwi-Boasiako ${ }^{1 *}$, G. Y. Coffie ${ }^{2}$ and N. A. Darkwa ${ }^{1}$ \\ 1Department of Wood Science and Technology, Faculty of Renewable Natural Resources, \\ Kwame Nkrumah University of Science and Technology, Kumasi-Ghana. \\ ${ }^{2}$ Forestry Commission, Bia Conservation Area, P. O. Box 171, Sefwi-Wiawso, Ghana.
}

Accepted 16 August, 2011

\begin{abstract}
Food selection by herbivores depends on the dietary composition of plant parts. However, the nutritional properties of tropical bamboo leaves, which could be a viable supplement of traditional fodder are hardly examined. Proximate composition of Bambusa ventricosa McClure, Oxytenanthera abyssinica (A. Rich.) Munro and two varieties of Bambusa vulgaris (B. vulgaris Schrad. ex J. C. Wendl. var. vulgaris Hort. and $B$. vulgaris Schrad. ex J. C. Wendl. var. vittata Rivière) leaves were determined. B. ventricosa proximately comprised $10.34 \%$ moisture, $1.38 \%$ crude fat, $11.56 \%$ ash, $19.02 \%$ crude protein, $27.20 \%$ crude fibre and $30.40 \%$ carbohydrate. $O$. abyssinica leaves contained $10.34 \%$ moisture, $1.38 \%$ crude fat, $12.56 \%$ ash, $19.39 \%$ crude protein, $26.78 \%$ crude fibre and $29.55 \%$ carbohydrate. $B$. vulgaris vulgaris had $10.34 \%$ moisture, $1.49 \%$ crude fat, $12.53 \%$ ash, $18.39 \%$ crude protein, $25.88 \%$ crude fibre and $31.38 \%$ carbohydrate, while $B$. vulgaris vittata contained $10.71 \%$ moisture, $1.58 \%$ crude fat, $8.73 \%$ ash, $18.75 \%$ crude protein, $33.19 \%$ crude fibre and $27.04 \%$ carbohydrate. Moisture content of bamboos is important, as it determines their susceptibility to microbial infection. The low moisture of the bamboo leaves is an index of the great shelf-life of their meal. These leaves are also a good aminoacid source (especially for $O$. abyssinica), while their carbohydrate and great fibre contents (as in $B$. vulgaris varieties) are a rich roughage supply. They are highly nutritious and could be used as alternative local feed resources suitably as fodder for livestock or wildlife and alongside other feed sources containing proteins and minerals to ensure food security in the tropics.
\end{abstract}

Key words: Bamboo leaves, crude protein, fodder, food energy, proximate analysis, shelf-life.

\section{INTRODUCTION}

Bamboo (Family: Poaceae) is a grass with a woody culm (stem), which is used often in construction much like conventional wood (Zehui, 2007; Anonymous, 2011a). At least, one third of the human race uses bamboo in one way or another (National Geographic Society, 1980;

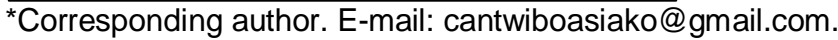

Abbreviations: NTFP, Non-timber forest product; FORIG, forestry research institute of Ghana; TNC, time non-structural carbohydrate content; AOAC, association of official analytical chemist; LSD, least significant difference.
INBAR, 1997). In East Asia in particular, ITTO (2009) reported that man cannot survive without bamboo, while the use of this plant is limited in the tropics. However, effective utilization for the whole plant would absolutely make it a suitable replacement for the traditional tropical timber species. Bamboo has a wide distribution in the tropics and sub-tropics ranging from latitude $46^{\circ} \mathrm{N}$ to $47^{\circ} \mathrm{S}$, and at elevations as high as 4,000 metres such as in the Himalayas and several parts of China to sea level in different areas (National Geographic Society, 1980; Liese, 1985). Four main species of bamboo have been recorded with several varieties in Ghana: Bambusa ventricosa McClure, Oxytenanthera abyssinica (A. Rich.) Munro and two varieties of Bambusa vulgaris (that is, $B$. 
vulgaris Schrad. ex J. C. Wendl. var. vulgaris Hort. and B. vulgaris Schrad. ex J. C. Wendl. var. vittata Rivière). The most widespread among these species, however, is $B$. vulgaris, which constitutes about $95 \%$ of the total bamboo resources. Two distinct varieties (that is, $B$ vulgaris var. vulgaris and $B$ vulgaris var. vittata) grow in Ghana and are regarded as native. The green variety (that is, $B$ vulgaris var. vulgaris) is more common than the yellow (that is, $B$ vulgaris var. vittata), which is often cultivated (Ebanyenle et al., 2005). This grass has many applications such as the production of panels, lumber, veneer, plywood, pulp and paper, charcoal, vinegar and flooring from their culms (Zehui, 2007). Bamboo is a major Non-Timber Forest Product (NTFP) whose exploitation should provide local people with sufficient food and fodder for their livestock and contribute to the development of herbal medicine as well as generate income (ITTO, 2009). Herbivores feed on plants based on their composition.

These include protein, phosphorus, and carotene (vitamin A), which are the principal components that may be limiting in plants on rangelands (Ruyle, 1993). These constituents occur in various above-ground parts of grasses such as the leaves. However, the inherent content of leaves is affected by leaf age, plant age and the position of the leaf (Harding et al., 1962; Marchal, 1984). Although, there is no documented evidence of the use of bamboo leaves as fodder in several developing countries, Farrelly (1984) reported that the giant panda feeds exclusively on bamboos, that is, their leaves, culms and roots. The leaves of $B$. vulgaris are very rich in nitrogenous material; they are a valuable feed, which cattle and horses eat with zest, while $B$. vulgaris and $B$. ventricosa are excellent sources of vitamin A. After harvesting culms of woody bamboo plants, livestock feed on their leaves as fodder, which is a common practice in China and Jamaica (Farrelly, 1984). However, this is hardly the situation in the tropical countries due to the paucity of information on their nutritional constituents (Ebanyenle et al., 2005). This research sought to provide compositional information on African bamboo leaves, which could be employed for livestock production in developing countries where animal food security is a problem. Thus, the study examined the proximate composition of four tropical bamboos so as to establish their nutritional suitability as fodder or feed for livestock or other animals. This can serve as a significant means of converting otherwise unusable parts of tropical bamboos into high quality animal protein.

\section{MATERIALS AND METHODS}

\section{Collection of bamboo leaves}

Leaves of $B$. ventricosa, $B$. vulgaris and $O$. abyssinica were collected from the bambusatum of the Forestry Research Institute of Ghana (FORIG) at the Bobiri Forest Reserve near Kumasi, in the Ashanti Region, which occupies about $10.2 \%$ of the total land area of Ghana. The area lies within a Moist Semi-Deciduous Forest type, while the soil is the Forest Ochrosol type. Rainfall is between 1250 to $1500 \mathrm{~mm}$ per annum with a bimodal pattern - a major in MayJune and the minor around September-October (Hall and Swaine, 1981). Green healthy bamboo leaves were plucked at random from $1.5 \mathrm{~m}$ above ground-level from three-and-a-half year old stands. Plucking was done just before the end of April at a time nonstructural carbohydrate content (TNC) levels were expected to be critically low (Wilson and Mannetje, 1978).

\section{Proximate analysis of bamboo leaves}

Leaf samples from each bamboo variety were individually subjected to proximate analysis using techniques prescribed by Association of Official Analytical Chemist [AOAC] (1990). This constitutes the class of food present in samples such as carbohydrate, protein, fat, fibre, ash and moisture contents (Iniaghe et al., 2009). Crude protein was determined using the micro-Kjedahl method (Shaw, 2006). Total ash was analyzed by incineration, crude fibre by incineration after acid and base digestion and crude fat by Soxhlet extraction. Moisture content was determined by oven-dry method and carbohydrates by difference (Pearson, 1976). There were triplicates for each analysis and their mean values and standard deviations determined. Composition of the bamboo leaves was compared with those established for three species of the high quality fodder, Acalypha (Family: Euphorbiaceae) determined by Iniaghe et al. (2009), elephant grass, Pennisetum purpureum (Okaraonye and Ikewuchi, 2009), cassava leaves (Manihot utilisima) and Talinum triangulare (Akindahunsi and Salawu, 2005; Iniaghe et al., 2009), Occimum graticimum and Hibiscus esculentus (Akindahunsi and Salawu, 2005) under similar conditions using the same protocols.

\section{Determination of energy content of bamboo leaves}

The total energy contents (that is, calorific values) of the bamboo leaves were determined based on the Atwater factor (FAO, 2006). These calorific values were compared with those determined by the bomb calorimeter. The amount of oxygen involved in the combustion of dry powdered leaf sample of each bamboo variety (1 g) was compared directly with the heat of combustion as determined in the calorimetric bomb (Mullan, 2006). Energy contents of the bamboo leaves were also compared with those of Acalypha (Iniaghe et al., 2009) and P. purpureum (Okaraonye and Ikewuchi, 2009), which were analyzed using the same standards.

\section{Statistical analysis}

Data obtained were subjected to Analysis of Variance (ANOVA) with values for $p<0.05$ considered significantly different. Least Significant Difference (LSD) was used to identify significant differences between treatment means.

\section{RESULTS}

\section{Proximate composition}

Proximate compositions of the sampled bamboo leaves are represented in Table 1. Except for the yellow variety of $B$. vulgaris (that is, B. vulgaris var. vittata), the most prominent constituent in all the varieties was carbohydrate, which ranged from $27.04 \%$ (for B. vulgaris 
Table 1. Proximate composition of dry powdered leaf samples for four tropical bamboo varieties.

\begin{tabular}{lcccc}
\hline${ }^{*}$ Nutrient (\%) & B. vulgaris vittata & B. vulgaris vulgaris & B. ventricosa & O. abyssinica \\
\hline Moisture & $10.71 \pm 0.21^{\mathrm{a}}$ & $10.34 \pm 0.34^{\mathrm{a}}$ & $10.34 \pm 1.98^{\mathrm{a}}$ & $10.34 \pm 0.09^{\mathrm{a}}$ \\
Ash & $8.73 \pm 0.49^{\mathrm{b}}$ & $12.53 \pm 0.21^{\mathrm{b}}$ & $11.56 \pm 0.08^{\mathrm{b}}$ & $12.56 \pm 0.18^{\mathrm{b}}$ \\
Protein & $18.75 \pm 0.05^{\mathrm{c}}$ & $18.39 \pm 0.03^{\mathrm{c}}$ & $19.02 \pm 0.04^{\mathrm{c}}$ & $19.39 \pm 0.02^{\mathrm{c}}$ \\
Crude fibre & $33.19 \pm 0.01^{\mathrm{d}}$ & $25.88 \pm 0.03^{\mathrm{d}}$ & $27.20 \pm 0.01^{\mathrm{d}}$ & $26.78 \pm 0.02^{\mathrm{d}}$ \\
Crude fat & $1.58 \pm 0.01^{\mathrm{e}}$ & $1.49 \pm 0.01^{\mathrm{e}}$ & $1.48 \pm 0.01^{\mathrm{e}}$ & $1.38 \pm 0.02^{\mathrm{e}}$ \\
Carbohydrate & $27.04 \pm 0.68^{\mathrm{f}}$ & $31.38 \pm 0.96^{\mathrm{f}}$ & $30.40 \pm 2.02^{\mathrm{f}}$ & $29.55 \pm 1.08^{\mathrm{f}}$ \\
Total & 100.00 & 100.00 & 100.00 & 100.00 \\
\hline
\end{tabular}

${ }^{*}$ Each value is a mean of triplicate determinations \pm standard deviation. Means (in same row) with different letters in superscripts differ significantly $(p<0.05)$.

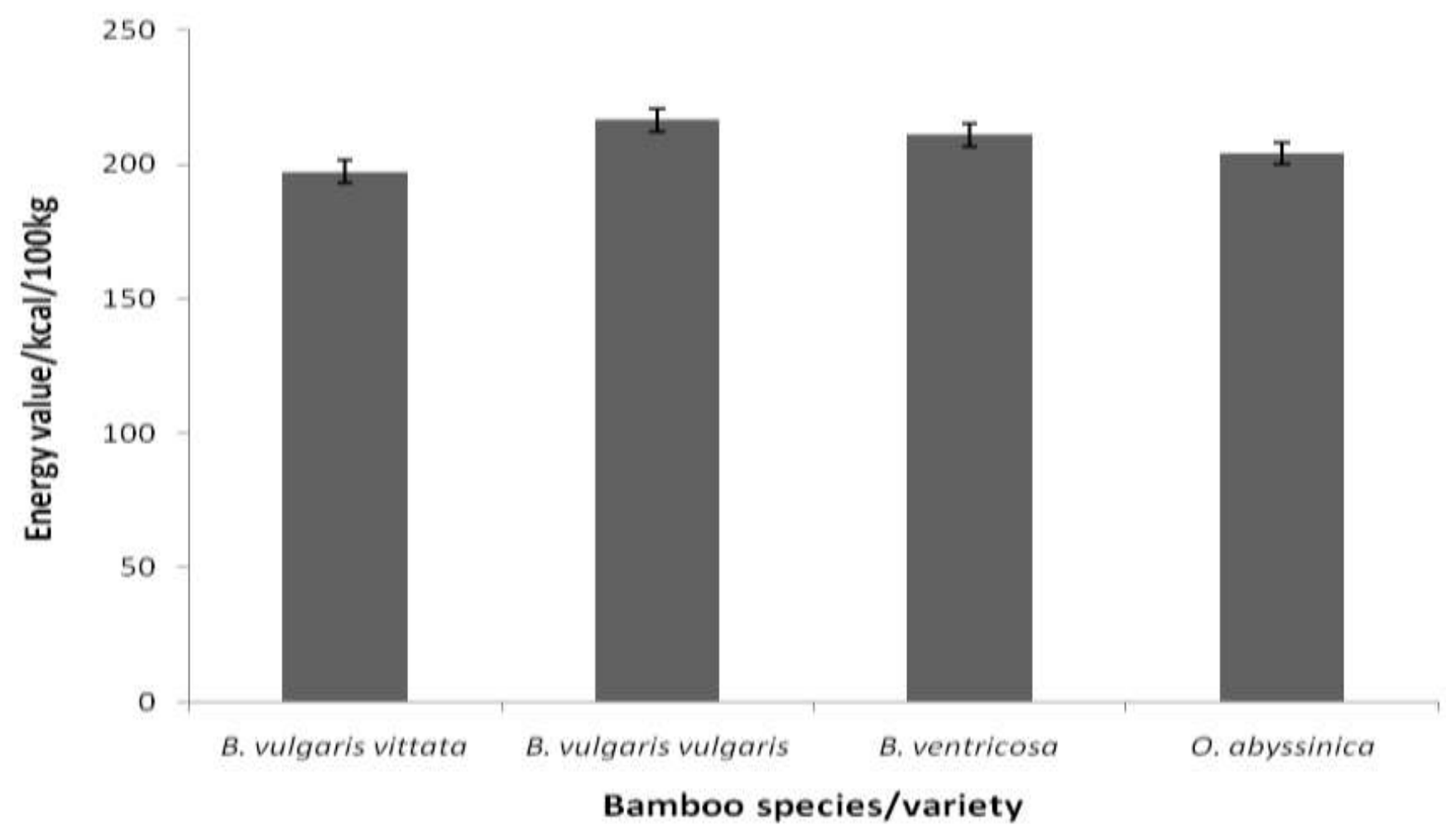

Figure 1. Food energy values for dry powdered leaf samples for four tropical bamboo varieties; NB: Conversion factor for the energy values $(\mathrm{kcal})=4.184($ Anonymous, 2011b).

vittata) to.31.38\% (for B. vulgaris vulgaris). The moisture and the total ash contents were very low in all the varieties. The lipid content of the leaves was extremely low (between $1.38 \%$ in $O$. abyssinica and $1.58 \%$ in $B$ vulgaris var. vittata). From the proximate analysis, the major components of bamboo leaves are: carbohydrates, crude fibre and protein; the three together constitute over $75 \%$ of the leaves. The leaves of B. vulgaris var. vittata have comparatively high crude fibre content $(33.19 \%)$ and very low total ash content (8.73\%). O. abyssinica leaves have the lowest crude fat content $(1.38 \%)$ but the highest ash (12.56\%) and protein (19.39\%) contents.
Table 1 shows that no significant differences $(p<0.05)$ exist between the values obtained for any one constituent among the bamboo varieties.

\section{Food energy values}

Calorific values for the leaves of the bamboo varieties, using a conversion factor of 4.184 (Anonymous, 2011b), are represented in Figure 1. The calorific values range from $826.19 \mathrm{~kJ} / \mathrm{g}$ (that is, $197.46 \mathrm{kcal} / \mathrm{kg}$ ) for $B$. vulgaris vittata to $906.18 \mathrm{~kJ} / \mathrm{g}$ (that is, $216.58 \mathrm{kcal} / \mathrm{kg}$ ) for $B$. 
vulgaris vulgaris. The differences between the energy values for the bamboo leaves are significant $(p<0.05)$ except between those for $B$. vulgaris vulgaris and $B$. ventricosa.

\section{DISCUSSION}

The carbohydrate values recorded for all the four tropical bamboo leaves were relatively lower than those recorded for those established for three notable species of the nutritious vegetable Acalypha. Iniaghe et al. (2009) recorded $48.48 \%$ for $A$. hispida, $45.26 \%$ for $A$. racemosa and $38.24 \%$ for $A$. manginata. However, the respective carbohydrate values for $O$. abyssinica, $B$. ventricosa and $B$. vulgaris vulgaris (that is, $29.55,30.40$ and $31.38 \%$ ) also compare favourably with that recorded by Okaraonye and Ikewuchi (2009) for the much grazed elephant grass, P. purpureum (that is, $30.91 \%$ ). Thus, like the much preferred fodder plant ( $P$. purpureum) by livestock and wildlife, these bamboo leaves are a good source of carbohydrates or energy. The relatively high crude fibre content of these bamboo leaves (that is, 25.88 to $33.19 \%$ ) suggests that animals will prefer them less to alternatives that have lower crude fibre such as $P$. purpureum, which has $9.09 \%$ (Okaraonye and Ikewuchi, 2009). These could explain why bamboo leaves are reported by Farrelly (1984) to impart superior physical tone and stamina to horses since fibre speeds up the process of digestion by improving peristalsis. According to the investigations made by Saldanha (1995) and UICC/WHO (2005), the high crude fibre content also means bamboo leaves of these varieties could be instrumental in colon cancer prevention in humans and in the treatment of obesity, diabetes and gastrointestinal disorders. The leaves of the bamboos showed crude protein content (18.39 to $19.39 \%)$ to be lower than that recorded for cassava ( $M$. utilisima) leaves, which contain $24.88 \%$, and $31.00 \%$ for $T$. triangulare (Akindahunsi and Salawu, 2005; Iniaghe et al., 2009).

However, the value is greater than those recorded for the three species of Acalypha (that is, 13.78, 16.19 and $18.15 \%$ for $A$. hispida, $A$. racemosa and $A$. manginata, respectively). Elephant grass and bamboo belong to the same family (Poaceae), yet the former has greater crude protein content $(27.00 \%)$ than that of any of the bamboo varieties analysed. This makes bamboo leaves a less nutritious feed source for high-protein demanding animals such as nursing cows and convalescents. Elephant grass will be a better alternative except that, unlike bamboo leaves, it contains high crude fat content (14.82\%), which such animals may find difficult to metabolise (Chaney, 2006). Moreover, the crude fat contents of the bamboo leaves, which range from 1.38 to $1.58 \%$, are lower than those recorded for the three Acalypha species (6.15, 6.30 and $6.60 \%$ for $A$. hispida, A. racemosa and $A$. manginata, respectively), Baseila alba (8.71\%), Amaranthus hybridus
(4.80\%) and $5.90 \%$ for T. triangulare (Akindahunsi and Salawu, 2005; Iniaghe et al., 2009). The little amount of crude fat for the bamboo leaves as well as their low moisture content would make bamboo leaves decayresistant, as these would limit the growth of decay microorganisms and prolong their storage lives (Adeyeye and Ayejuyo, 1994). Thus, the efficacy or bioactivity of extracts from the bamboo leaves as a potential organic preservative in preventing bio-deterioration of on-farm wooden structures and other natural resources, where toxic conventional inorganic preservatives may be undesirable, need investigating. The ash content of the bamboo leaves was great (ranging from $8.73 \%$ for $B$. vulgaris vittata to $12.56 \%$ for $O$. abyssinica), which suggests their possession of a large deposit of mineral elements (Antia et al., 2006).

Although their ash contents compare with those of several vegetables including $O$. graticimum and $H$. esculentus (that is, $8.00 \%$ ) reported by Akindahunsi and Salawu (2005), they are by far less than those recorded for the leafy vegetable $T$. triangulare $(20.05 \%)$, which is often used as a palatability improver in pasture as well as the valuable forage, $P$. purpureum (18.18\%). However, they are greater than $3.17 \%$ recorded for chestnuts (Castenea spp.) (Amoo et al., 2008). Geography affects the bio-chemistry of organisms, particularly plants. The ash content of plants is directly related to the mineral composition of the soil, that is, their growth sites. This situation is evidenced by the fact that previous figures for various bamboo species collected from different parts of the world by FAO (2006) ranged from 3.3\% especially for Arundinaria cannaviera collected in Brazil to $16.9 \%$ for $B$. vulgaris collected in Jamaica (INBAR, 2010). Thus, the ash contents for these tropical varieties (8.73 to $12.56 \%)$ appear unique. Even though the bamboo leaves contain low crude fat, their protein and high carbohydrate values compensate, to an extent, for their relatively high energy values. Chestnut and sponge gourd (Luffa aegyptica) have energy values of $542.29 \mathrm{kcal}$ and $451.97 \mathrm{kcal}$, respectively (Amoo et al., 2008), while Okaraonye and Ikewuchi (2009) recorded 313.45kcal for $P$. purpureum.

However, the average energy value for the bamboo leaves under investigation is $207.26 \mathrm{kcal}$, using a conversion factor of 4.184 (Anonymous, 2011b). Based on high carbohydrate and protein contents, coupled with the calorific values, bamboo leaves are suitable for the feeding of animals. Thus, they could be fed to livestock as fodder just like the highly palatable and most valuable forage, $P$. purpureum. However, these leaves alone should be fed to animals preferably in large quantities (the abundance of $B$. vulgaris especially will support this) to compensate for its deficiencies, or as a therapy for obesity, diabetes, gastrointestinal disorders, and prevention of colon cancer or in combination with other feed sources containing higher levels of protein and total ash (minerals). This would promote the efficient and sustainable whole utilization of the tropical bamboos, 
which would otherwise pose a major waste disposal problem. Utilization of the leaves would contribute to broaden the raw material base for non-timber wood products usually employed as a fodder source for farm animals in developing countries, especially in areas where it is increasingly difficult to maintain food security.

\section{Conclusion}

The proximate composition of the four important tropical bamboos reveals that their leaves are carbohydrate-rich when compared with components of the leaves from several vegetables, which are usually employed as forage or palatability improvers in pasture. Their low moisture content is an index of their great permanence due to less microbial susceptibility and long shelf-life of their meal. Their average protein content is a source of amino-acid, while their great fibre, coupled with great carbohydrate contents, would serve as a rich roughage supply. Lack of fodder in developing countries, for the greater parts of the year (especially at the long dry periods), poses a grave threat to food security, as these do not make animals in these localities productive. Thus, the feeding of livestock and other animals using the nutritious leaves of these bamboos as fodder is viable depending on their nourishment or therapeutic needs.

\section{ACKNOWLEDGEMENT}

The authors are grateful to the Management and Staff of the Forestry Research Institute of Ghana (FORIG), Fumesua, Kumasi, Ghana, for the bamboo leaf samples from their bambusatum and Dr. Samuel Osafo-Acquah (Department of Chemistry, Kwame Nkrumah University of Science and Technology, Kumasi) for the technical advice.

\section{REFERENCES}

Adeyeye El, Ayejuyo OO (1994). Chemical composition of Cola accuminata and Garcinia kola seeds grown in Nigeria. Int. J. Food Sci. Nut,. 45: 223-230.

Akindahunsi AA, Salawu SO (2005). Phytochemical Screening and nutrient-antinutrient composition of selected tropical green leafy vegetables. Afr. J. Biotechnol,. 4: 497-501.

Amoo IA, Emenike AE, Akpambang VOE (2008). Chemical Composition and Nutritive Significance of Luffa aegyptica and Castenea $s p$. Seeds. Trends Appl. Sci. Res., 3(4): 298-302.

Anonymous (2011a). Bamboo Engineered Housing: Challenges and Opportunities for Bamboo Engineered (Pre-fabricated) Housing in Nepal. Housing Nepal.com (A Spiral Venture_Presentation).

Anonymous (2011b). Calorie, Variations and Conversions. Wikimedia Foundation, Inc., Wikipedia Encyclopaedia (2011) [http://en.wikipedia.org/wiki/Calorie: Accessed 6 January 2011].

Antia BS, Akpan EJ, Okon PA, Umoren IU (2006). Nutritive and AntiNutritive Evaluation of Sweet Potatoes (Ipomoea batatas) Leaves. Pakistan J. Nutr., 5: 166-168.

AOAC (1990). Official Methods of Analysis. Association of Official Analytical Chemists. $15^{\text {th }}$ ed. Washington D.C., U S A.
Chaney SG (2006). Principles of Nutrition I: Macronutrients. In: Devlin TM (Ed.). Textbook of Biochemistry, with Clinical Correlation. $6^{\text {th }}$ ed. John Wiley and Sons, New York, pp. 1071-1090.

Ebanyenle E, Ameyaw K, Oware J (2005). Ghana's Bamboo Industry: Country Report, Paper presented to Bamboo Technology Training Course, Hangzhou, China.

FAO Corporate Document Repository (2006). Calculation of the Energy Content of Foods - Energy Conversion Factors [http:/www.fao.org/ag].

Farrelly D (1984). The Book of Bamboo. The Sierra Club, San Francisco, CA. USA, pp. 278-280.

Hall JB, Swaine MD (1981). Geobotany: Distribution and Ecology of Vascular Plants in Tropical Rainforests. Forest Vegetation in Ghana, Dr. W. Junk Publishers, London, UK, P. 321.

Harding RB, Ryan TM, Bradford GR (1962). A Comparison of Macroelement Composition of Orange Leaves from Non-Fruiting and Fruiting Terminals. Proc. Soc. Am. J. Hortic. Sci., 80: 255-258.

INBAR (1997). International Network for Bamboo and Rattan (INBAR) Newsmagazine: Special Edition, 5(3): 56.

INBAR (2010). Bamboo and Rattan Facts. http://www.inbar.int/Board.asp?Boardid=173 [Accessed 23 December 2010].

Iniaghe OM, Malomo SO, Adebayo JO (2009). Proximate Composition and Phytochemical Constituents of Leaves of Some Acalypha Species. Asian Network for Scientific Information, Pakistan J Nutr., 8 (3): 256-258.

ITTO (2009). Gifts from the Forest. International Tropical Timber Organisation (ITTO) Technical Series 32, Yokohama, Japan, P. 15.

Liese W (1985). Bamboo - Biology, Silviculture, Properties and Utilization. GTZ, Eschborn, Germany, P. 33.

Marchal J (1984). Citrus. In: Plant analysis as a guide to the nutrient requirements of temperate and tropical crops: Martin-Prevel et al. (Eds.); Lavoisier Publishing Inc., New York, pp. 320-354.

Mullan WMA (2006). Labelling-Determination of the energy content of food. [On-line]. Available from: http://www.dairyscience.info/packaging-/119-labelling-determinationof-the-energy-content-of-food.html [Accessed 29 January 2011].

National Geographic Society (1980). Bamboos the Giant Grass, Nat Geo Magazine. 158 (4): Garret WE, Judge J [Eds.], P. 516.

Okaraonye CC, Ikewuchi JC (2009). Nutritional and Antinutritional Components of Pennisetum purpureum (Schumach). Pakistan $\mathrm{J}$ Nutr., 8 (1): 32-34.

Pearson D (1976). The Chemical Analysis of Foods. $7^{\text {th }}$ ed. Churchill Livingstone, London, pp. 15.

Ruyle G (1993). Range Cattle Nutrition, Arizona Ranchers' Management Guide. Gum R, Ruyle G, Rice R (Eds.). Arizona Cooperative Extension.

Saldanha LG (1995). Fibre in the diet of U. S. Children: Results of national surveys. Paediatrician. (96): 994-996.

Shaw J (2006). Kjeldahl Nitrogen Analysis, FDST 4070, P. 7-15.

UICC/WHO (2005). Global Action Against Cancer Now. Geneva: UICC and WHO Publications Department.

Wilson JR, Mannetje LT (1978). Senescence, digestibility and carbohydrate content of buffel grass and green panic leaves in swards, Aust. J. Agr. Res., 29 (3): 503-516.

Zehui J (2007). Bamboo and Rattan in the World. China Forestry Publishing House. $1^{\text {st }}$ ed. Beijing, China, P. 360. 